\title{
Electricity Pricing Policy Alternatives to Control Rapid Electrification in Korea
}

\author{
Changseob Kim* and Jungwoo Shin ${ }^{\dagger}$
}

\begin{abstract}
Although South Korea experienced a rolling blackout in 2011, the possibility of a blackout in South Korea continues to increase due to rapid electrification. This study examines the problems of energy taxation and price distortions as possible reasons for the rapid electrification in South Korea, which is occurring at a faster rate than in Japan, Europe, and other developed countries. Further, we suggest new energy taxation and price systems designed to normalize electricity prices. In order to do so, we consider two possible scenarios: the first imposes a tax on bituminous coal for electricity generation and the second levies a tax to provide compensation for the potential damages from a nuclear accident. Based on these scenarios, we analyze the effects of a new energy system on electricity price and demand. The results show that a new energy system could guarantee the power generation costs and balance the relative prices between energy sources, and could also help prevent rapid electrification. Therefore, the suggested new energy system is expected to be utilized as a basis for energy policy to decrease the speed of electrification, thus preventing a blackout, and to induce the rational consumption of energy in South Korea.
\end{abstract}

Keywords: Electrification, Electricity price, Social cost, Integrated energy tax

\section{Introduction}

Various studies on the imbalance of supply and demand have been conducted as both the economy and the demand for energy have grown. In the cases of oil, gas, coal, nuclear, and renewable energy, research has been carried out to examine the risks and vulnerabilities for an economy if a nation ceases its energy imports [1-4]. Electricity, on the other hand, is one of the grid energies and thus needs to be examined in terms of the imbalance of supply and demand in order to avoid a blackout caused by structural defects.

Recently, the rate of electrification has increased as the economy grows, which leads to an increased possibility of blackouts; hence, it has emerged as an important issue $[5,6]$. The causes of a blackout are various; they may include such things as problems with the electric power transmission system, power plant failure or poor demand forecasting [7]. The main cause of a massive power failure is the temporary interruption of the power supply caused by a problem with the transmission system and power plant. Representative examples of large-scale blackouts in the United States, Canada, and Italy in 2003 and in the European Union (EU) in 2006 were caused by the collapse of the transmission system [6]. In Korea ${ }^{1}$ in

$\dagger$ Corresponding Author: Environmental Policy Research Group, Korea Environment Institute, Korea. (shinjung11@gmail.com)

* Dept. of Energy IT, College of Engineering, Gacheon University, Korea. (cskim407185@gmail.com)

Received: January 23, 2015; Accepted: October 18, 2015
2003, power transmission lines were broken owing to a typhoon and a blackout occurred in some areas.

However, unlike the cases mentioned above, the heightened risk of blackout in Korea is caused by rapid electrification, not by deficiencies in the generation or transmission capacity. ${ }^{2}$ The electrification of energy is a phenomenon that occurs naturally along with economic growth, but the imbalance of supply and demand in Korea has occurred because the pace of electrification is too fast. Since 2003, the electric power reserve rate ${ }^{3}$, which represents the adequacy of the electricity supply, has continuously decreased. According to [8], the electric power reserve rate was $9.6 \%$ in 2006 but has fallen below $5.0 \%$ since 2011 .

The reason for the decreasing electric power reserve rate in Korea is the failure in forecasting the demand for electricity. In fact, the average annual growth rate of electricity demand was forecasted to be about $2.4 \%$ by the Korea National Energy Master Plan 2006-2011, but the actual annual growth rate of electricity demand during that period was $4.8 \%$. Owing to the characteristics of energy,

\footnotetext{
${ }^{1}$ Unless otherwise noted, in this paper Korea indicates the Republic of Korea (South Korea)

2 Since the rolling blackout in September 2011, a continual risk of blackout has remained. The rapid pace of electrification has been mentioned as one of the main factors contributing to the risk of blackout in Korea

3 The electric power reserve rate is defined as the ratio of the difference between the total generation and the maximum demand to the maximum demand of electricity. This can be expressed in following equation: electric power reserve rate $=\{($ total generation - maximum demand $)$ (maximum demand) $\} \times 100$.
} 
planning for supply capacity is generally conducted for a long time (such as 10 years) before it is need; it is difficult to change the capacity significantly in the short term. Excessive growth of electricity demand beyond the forecasted capacity can lead to a blackout, meaning that the exorbitant electrification of energy is a very critical issue in terms of national energy security in Korea.

Considering the volatile nature of electricity demand, various policies have been implemented to solve the energy security problem and many academic researches have been conducted to evaluate their impacts. From the supplyside, [9] tried to estimate the impacts of policy scenarios in Japan from the perspective of power generation, and [10] investigated this issue from the load control and power system operation. On the demand-side, [11] and [12] examined the effectiveness of demand response system with several case studies of European countries. However, supply-side schemes in common have limitations of high installation cost and long-term issues, whereas demand side management (DSM) may increase the complexity of operation and its effectiveness has yet to be further assessed.

In Korea, rather than poor demand forecasting and other energy problems rapid electrification is a critical problem, because the rapid increase in electricity demand is attributed to a structural problem of taxation and the pricing system in the electric market. First, the price of electricity in Korea is significantly lower than in most other countries. This contributes to a twofold increase in electricity consumption, which includes the transition of demand from diesel fuel heaters to electric heaters, whereas Japan and the OECD European countries have reached saturation in their electricity consumption. In addition, electricity generation costs were set lower than actual costs owing to the price stability of consumer goods and services ${ }^{4,5}$. Therefore, low electricity prices have promoted additional electricity demand and the transition of demand to other energy sources such as diesel and kerosene. In addition, electricity pricing differentiated by use has caused a cross-subsidy between consumer segments. The electric power supply structure and pricing system have remained relatively unchanged since the 1980s, and this has caused an entrenched structure

\footnotetext{
${ }^{4}$ The Korea government imposed only $1 \%$ tariff on bituminous coal which is a fuel for electricity generation, but $3 \%$ tariff was imposed on other fuels for transport and heating such as LNG and gasoline. In addition, except for tariff, no tax has been imposed on uranium or bituminous coal for electricity generation, but the individual consumption tax, transportation energy, environment tax, educational tax, district traveling tax and the import levy tax were imposed on other fuels. In addition, to attain price stability, the Korea government has controlled electricity price and they set the electricity price as $88.4 \%$ of electricity generation costs in 2012. Due to these taxation and pricing policy, lower electricity price was set in Korea.

5 According to [13], the increasing price of electricity affects the prices of consumer goods and services. Therefore, the Korean government set the electricity price to be lower than the actual cost in order to prevent an increase in the prices of consumer goods and services.
}

resulting in inefficient energy consumption in the industrial sector.

To solve the energy problems related to electrification such as the transition of demand to electricity and the increased possibility of blackouts, an improved direction for energy policy is required. Demand-side rather than supply-side solutions can be useful in dealing with rapid electrification in the short term, but demand-side solutions cannot figure out distortions in the energy consumption structure fundamentally. Therefore, we consider a new energy taxation policy to change the energy consumption structure in Korea. Moreover, an integrated perspective on this problem and systematic improvements are needed because a single energy policy for a specific energy source could affect various parts of other energy sources. For this reason, interested parties have consistently called for an integrated approach concerning energy taxation and electricity prices $[14,15]$.

This study examines the distorted energy market in Korea and its adverse effects on the national economy. In addition, a possible reorganization plan for energy taxation and electricity prices designed to mitigate the distortion in the energy markets is discussed. More specifically, quantitative analysis is performed based on the available data to identify the effect of the change on tax revenues, which is the most controversial part with respect to energy taxation and electricity rates. Moreover, more realistic and effective reorganization directions are suggested by using scenario analysis, which analyzes the impact of the reorganization of the tax revenues and electricity prices under the principle of neutral taxation for integrated management of energy taxation and electricity prices.

This paper is organized as following: The next section offers a brief discussion about related researches on energy saving strategies. In Section 2, we review the background of rapid electrification in Korea; We examine Korea's electrification of energy and compare it with trends in major foreign countries and with the individual electrification status of the industry, household, and business sectors. In addition, the causes and problems of Korea's energy electrification are analyzed using an integrated perspective. In Section 3, a plan for the reorganization of energy taxation and electricity prices is suggested in order to alleviate the trend of electricity consumption, and in Section 4, the changes in tax revenues and change in the electricity prices caused by the proposed restructuring plan are analyzed. Finally, Section 5 presents the implications of this study.

\subsection{Previous researches on energy saving strategies}

Regarding the trend of increasing electricity consumption, several literatures have tried to estimate the impacts of policy adopted. Reflecting the rapidly changing nature of electricity demand, recently published works suggested various methodologies to approach this question. 
Table 1. Previous studies on electricity saving strategies

\begin{tabular}{c|l|l|l}
\hline Research & \multicolumn{1}{|c|}{ Research target / country } & \multicolumn{1}{|c}{ Methodology } & \multicolumn{1}{|c}{ Key results and main findings } \\
\hline$[11]$ & Electricity System / UK & $\begin{array}{l}\text { - Policy scenarios } \\
\text { - Simulation }\end{array}$ & $\begin{array}{l}\text { Electricity DSM can increase the efficiency of system } \\
\text { investment given low utilization of generation and } \\
\text { networks. }\end{array}$ \\
\hline$[12]$ & DR / EU (UK, Italy, Spain) & $\begin{array}{l}\text { - Policy analysis } \\
\text { - In-depth case studies }\end{array}$ & $\begin{array}{l}\text { Limited knowledge, high cost estimates, and market } \\
\text { liberalizing policies led to slow DR emergence. }\end{array}$ \\
\hline$[16]$ & $\begin{array}{l}\text { Different policy and technology } \\
\text { choices / Countries including USA }\end{array}$ & $\begin{array}{l}\text { - Policy analysis } \\
\text { - In-depth case studies }\end{array}$ & $\begin{array}{l}\text { Energy saving technologies can help consumption } \\
\text { reduction, but effective public policies are also needed. }\end{array}$ \\
\hline$[17]$ & Non-price interventions / USA & $\begin{array}{l}\text { - Difference-in-differences estimator } \\
\text { - Regression Discontinuity design }\end{array}$ & $\begin{array}{l}\text { Non-price interventions can effectively reduce average } \\
\text { energy consumption. }\end{array}$ \\
\hline$[18]$ & Non-price interventions / USA & $\begin{array}{l}\text { - Control and treatment group } \\
\text { - OLS regression }\end{array}$ & $\begin{array}{l}\text { Peer comparison intervention can help driving energy } \\
\text { reductions. }\end{array}$ \\
\hline$[9]$ & Future electricity scenarios / Japan & $\begin{array}{l}\text { - Policy scenarios } \\
\text { - Input-output hour-by-hour simulation } \\
\text { model }\end{array}$ & $\begin{array}{l}\text { Renewable energy generation can reduce the dependence } \\
\text { on other sources, but still needs more flexible power } \\
\text { sources for fluctuations. }\end{array}$ \\
\hline$[10]$ & $\begin{array}{l}\text { Load control and power system } \\
\text { operation }\end{array}$ & $\begin{array}{l}\text { Hierarchical control architecture is most promising by } \\
\text { providing a seamless route to fit aggregated load into the } \\
\text { legacy control paradigm. }\end{array}$ \\
\hline
\end{tabular}

We would be able to align these literatures according to demand-side approaches and supply-side approaches (See Table 1).

First, several studies tried to investigate the demand management of electricity from consumers' side, mostly from short-term views. [13] examined the benefits and challenges of DSM of UK electricity system. They considered DSM as a possible contributor to reduce the generation margin bringing benefits of about $£ 250-£ 400 / \mathrm{kW}$ in their modern gas-fired-type plant. [12], recognizing the importance of consumer behavior, provided some case studies from UK, Italy, and Spain. In this study, they found that high cost estimates and policies focusing on liberalizing EU energy markets led to slower emergence of demand response. [19] provided more information of DSM from the structure and mechanism with challenges. In addition, they also contained the information from the recent demonstrations in EU. More specifically on the topic of electricity usage in industrial sectors, [16] presented methods to control the electricity demand via technological advances (e.g. high efficiency motors, leak prevention in air compressors) and policy adoptions (e.g. increased export taxes on energy-intensive industries in China) with several national-level case studies. However, challenges for DSM still remain, such as lack of ICT infrastructure, increased complexity of the system operation compared with traditional methods, and thus DSM-based solutions need to be assessed further in economic and environmental ways as [11] mentioned.

Other more socio-political demand-side approach also showed positive yet decreasing effects on demand reduction. [17] analyzed the impacts of non-price interventions that were represented by sending Home Energy Report letters to household electricity customers who had their electricity use data compared with those of their neighbors. Although the effects were heterogeneous due to the different social norms, the program in general reduced energy consumption.
[18] used the data from same energy firm, and reached a similar conclusion that regularly mailed peer feedback reports helped reduction in energy consumption, though the effects decreased over months.

On the other hand, supply-side approaches have a long period of time to examine their findings. [10] examined opportunities and challenges of implementing non-disruptive control strategies, and emphasizing the importance of communication infrastructure in designing a control paradigm. [9] chose Japanese electricity industry to suggest policy scenarios to cope with the recent accident, and they also considered expanding trend of renewable energy. They simulated their scenarios of negative, conservative, and active pursuit of nuclear power until 2030 and anticipated the dependence level and cost related to capacity factor. They suggested that matching the demand level with lower thermal power plants and more renewable energy will increase the cost, in their example cost is increased from 7 yen $/ \mathrm{kWh}$ to 8 yen $/ \mathrm{kWh}$.

Supply-side discussions in adopting new technologies also showed interesting implications. [20] presented photovoltaic generation for self-consumption enhancement, with an electrical demand-side management system that could be commanded by the users to control the selfconsumption rates. [21] suggested the Microgrid operation - low voltage distribution networks with various distributed generators - along with demand site bidding can be economically beneficial to either suppliers or consumers. According to their analysis with Microgrid market policies, active power prices for consumers can be reduced by $21.53 \%$ or profits for the aggregator can be increased by 102 Euros. However, as limitations, the supply-side schemes in common have high installation costs that can delay the policy implementation. In addition, characteristics of long-term plans make supply-side approaches less relevant with short-term volatility which requires flexible adjustments. 


\section{Background of Korea's Electrification}

\subsection{Electrification of energy}

Korea has achieved continuous economic growth; this growth has been accompanied by a quantitative increase in its energy consumption. However, after the financial crisis in the late 1990s, the amount of energy consumed along with the structure of final energy consumption changed significantly. Quantitative changes in energy consumption are related to change in the growth rate of the domestic economy, such as the global financial crisis, but the structure of energy consumption, i.e., the change in the energy mix, has been affected by the change in energy prices. In this section, the trends in the change in final energy consumption structure of petroleum, city gas, electricity and liquefied petroleum gas (LGP) as the center (excluding the bituminous coal industry and naphtha feedstock) are examined in order to consider the key target of this study, the problem of energy electrification.

\subsubsection{Electricity consumption trend in korea}

As shown in Fig. 1, final energy consumption showed a marked change following the financial crisis in the late 1990s. First, the consumption of oil increased rapidly prior to the financial crisis and declined rapidly thereafter; LPG saw a gradual increase until recently when it entered a downward trend. Meanwhile, the consumption of electricity and city gas is continuously increasing. The growth rate of electricity in particular recently surpassed that of city gas, and the increasing trend is accelerating. Therefore, we can say that the most significant change in final energy consumption can be summarized as a surge in demand for electricity and city gas in recent decades in Korea.

A reduction in oil consumption and an increase in the consumption of electricity and city gas are results of an increase in national income and economic growth. However, the problem lies in the rate of increase in electricity demand in Korea; it is too rapid compared to other countries and Korea's electricity generation capacity

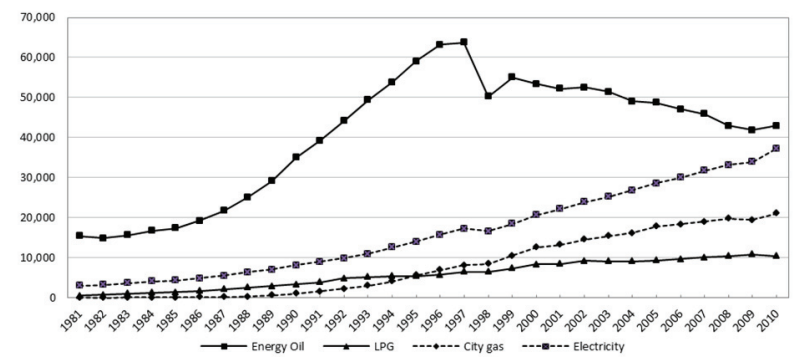

Fig. 1. Main trend in final energy consumption (Unit: 1,000 TOE)

Source: [22]

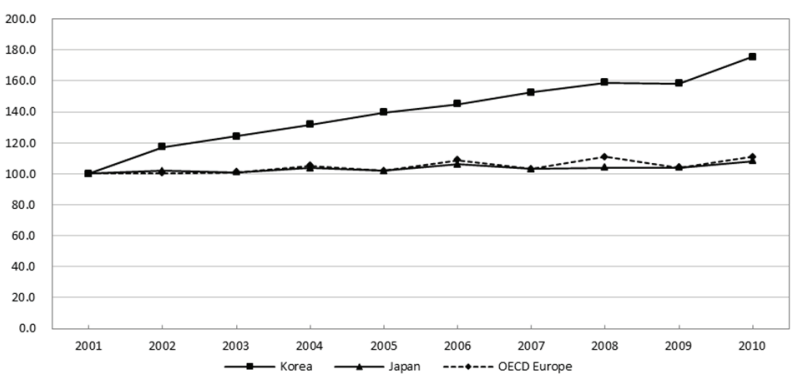

Fig. 2. Comparison of the increase in electricity demand per household among Korea, Japan, and OECD European countries

Source: [23-27]

Note: The data difference between reports is revised based on the data in 2012. The level in 2001 is assumed to be 100 , and then the relative ratio is calculated in each country.

cannot catch up with the increase in demand. In fact, the reserve rate of an electric power plant in Korea decreased from $15.3 \%$ in 2004 to $4.1 \%$ in 2011 , according to [8].

Fig. 2 shows the increases in electricity demand per household in Korea, Japan, and OECD European countries in the past decade. The reasons why we chose Japan for comparison are as following: The first reason is the similarity of electricity grid which is isolated from surrounding nations; The second reason is that they are similar in terms of the lack of natural resources; The third reason is the similarity of economic structure which shows high portion of manufacturing sector and has a high level of dependence on exports. Due to the second reason, we also chose OECD European countries ${ }^{6}$. In this study, we did not compare the electricity demand in Korea with other countries such as United States and Australia, because they have plenty of natural resources in contrast with Korea, Japan and OECD European countries. Electricity demand in Japan and the OECD European countries almost reached saturation, whereas electricity consumption in Korea in the past decade nearly doubled. Even given the fact that Korea's industry structure is based on an export-oriented manufacturing industry, the growth rate of electricity consumption is still excessive.

\subsubsection{Electrification by energy source}

As described above, an examination of the energy consumption patterns in Korea finds a sharp increase in electricity consumption and a decrease in oil consumption beginning in 1997. This was driven by low electricity prices relative to other energy sources coupled with fuel taxation hikes that began in the late 1990s and occurred in all sectors except the transportation sector owing to the rise

\footnotetext{
${ }^{6}$ Due to the Euro Crisis in 2008, electricity demand in OECD European countries sharply decreased in 2009. However, according to [22] electricity demand in 2010 was recovered from the Euro Crisis, and it showed that electricity demand in OECD European countries were almost saturated.
} 
in crude oil prices in the 2000s. Looking at actual electricity consumption by category, various forms of heating and drying energy were replaced by electricity in the manufacturing sector, and the fuel used for drying farm and marine products in the agriculture and fishery sectors was replaced by electricity. In addition, fuel used for heating in the commercial and residential sectors was also replaced by electricity. Conversion of energy demand into electricity is a global trend. However, Korea's electrification trend is unparalleled in the countries of net energy importers, which has induced the recent supply crisis in electricity and an inefficient energy consumption structure. In the following section, we examine one of the categories of final electricity consumption, heat demand, which is the main cause of conversion demand. This study mainly deals with the electrification of heat demand in the industry sector (manufacturing division) and the household and business sectors.

\section{The Electrification of Heat Demand in the Industry Sector}

The industry sector in Korea, the manufacturing sector in particular, accounted for about $53 \%$ of overall electricity consumption (excluding coal and stock oil), and the trend of switching from fossil fuels to electricity is a main factor leading to the electricity supply crisis. Fig. 3 presents data on energy consumption patterns by energy source in Korean manufacturing. According to the [28], while electricity accounted for $43.3 \%$ of total energy consumption in 2001, that figure expanded rapidly to $55.4 \%$ in 2010 . Oil consumption showed a sharp decline to $12.6 \%$ from $36.2 \%$ over the same time period. Price distortions in the fossil fuel and electricity markets are seen as a main cause of the rapid electrification of the manufacturing industry.

According to the energy consumption survey [29] issued every three years, energy used in the industrial process in Korean manufacturing is classified into the following categories: indirect heating (boiler), direct heating (heating/drying machine), electrochemical (furnace/oven),

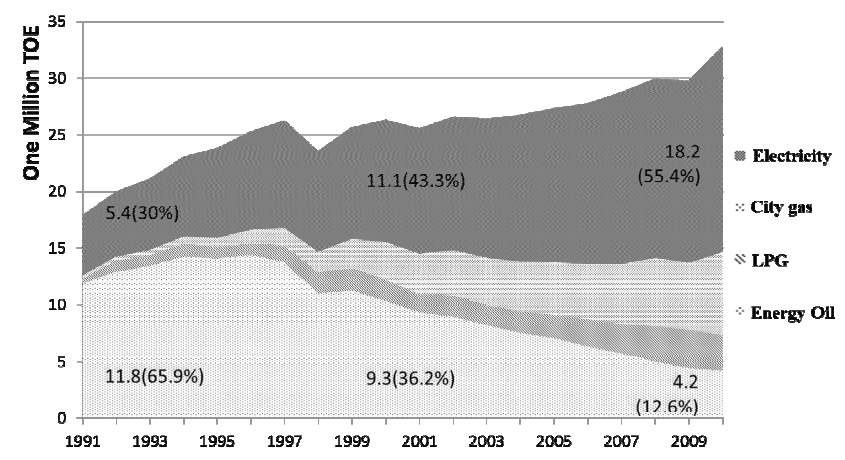

Fig. 3. Consumption trends in the domestic manufacturing sector (excluding coal and stock oil)

Source: [28] power (electric motor/etc.), and other (heating, lighting, etc.). Electricity consumption from processing equipment increased about 64\% from 2001 to 2010. Power demand from heating/drying also increased rapidly, while demand from the power category decreased or remained stagnant. In particular, electricity demand of heating/drying led to an increase in overall electricity demand from industry reaching $70 \mathrm{TWh}$ in 2010 , up from $17.8 \mathrm{TWh}^{7}$ in 2001 , which is about a $293 \%$ increase over the period. Unlike the process of precision casting, the heating/drying process uses low-level energy sources such as oil, but oil consumption was partially converted to electricity. The energy conversion mainly contributes to the rapid electrification and the immobilization of an inefficient energy consumption structure.

Oil consumption fell 52.2\% during the period from 2001 to 2010. This category includes gasoline, kerosene, diesel oil, light fuel oil, heavy oil, heavy fuel oil, propane, butane, naphtha, and other oils; the majority of the decline is in consumption of heavy fuel oil (Bunker-C). The rate of consumption of heavy fuel oil decreased approximately $72.5 \%$ from 29.8 Tera cal. $^{8}$ in 2001 to 8.2 Tera cal. in 2010 owing to environmental regulations related to greenhouse gas emissions and the conversion to cheap electricity.

\section{The Electrification of Heating Energy in the Household / Business Sectors}

Another example of energy electrification in Korea is a rapid increase of electric heating in the household and business sectors during the winter season. Electricity consumption in all four seasons has increased rapidly, but the increase in electricity consumption during the winter season is the most striking. In the early mid-2000s, electricity demand in winter exceeded demand in the other seasons for the first time. There was a sharp depreciation of the Korean currency owing to the financial crisis in the late 1990s and a one-off rise in international crude oil prices in 2000; this rise in oil prices temporarily promoted electricity consumption. However, since the exchange rate continued to fall after the early 2000s, and crude oil prices also dropped until 2003, it is difficult to see these as critical factors for electrification. We suppose that the spread of electric heaters at midnight may serve as a decisive reason for the rapid increase in electricity demand during winter in the early 2000s [15]. The surge of midnight electricity consumption is attributed to the differences in relative price per available heat between midnight electricity and kerosene. ${ }^{9}$ In other words, the mismatch of electricity pricing policy and energy tax policy in the early 2000s induced diffusion of residential electric heating; thus, it is considered one of the main factors contributing to the rapid

\footnotetext{
$\mathrm{TWh}=$ Tera Watt hour $=10^{12}$ Watt hour

8 Tera cal. $=10^{12}$ calorie

9 In the early 2000 s, the price of midnight electricity was set to be lower. Therefore, midnight electricity consumption for heating rapidly increased.
} 
increase in winter electricity demand, which surpassed demand in other seasons in the early 2000s.

In order to reduce the pace of electrification at night, the new subscriptions for the midnight electricity service, of which the electricity price was set to be lower than the average price of electricity, was stopped. Therefore, the growth rate of electrification at night was eased. However, the use of electric heating appliances in commercial sectors in cities such as electric heating products began to spread rapidly from the late 2000s. Business heating load has increased rapidly since the late 2000 s and has surpassed the industry heating load. According to [8], the demand for electric heating based on the maximum load increased to $9 \mathrm{GW}$ in $2004,11 \mathrm{GW}$ in $2006,14 \mathrm{GW}$ in 2008 , and $18.6 \mathrm{GW}$ in 2010; electric heating reached $25.4 \%$ in 2011 .

\section{Causes and Issues of Electrification in Korea}

The reasons for the phenomenon of electrification are various, but the effect of relatively low electricity prices could be a main driver of rapid electrification. In this section, energy tax and electricity pricing policy in Korea, important elements in the structure of the energy price system, are considered. In addition, in order to examine the cause of rapid electricity consumption, relative prices between fuel and electricity are compared.

\subsection{Energy taxation policy in korea}

In terms of the energy tax system, there is a relatively high tax on oils, but the energy sources associated with electricity generation are nearly tax free in Korea. Table 2 shows the energy tax system in January 2012. In the case of fuels, the tariff is $3 \%$, but bituminous coal as a fuel for electricity generation has only $1 \%$ tariff, so it is nearly tax exempt. In addition, The individual consumption tax; transportation energy, environment tax; educational tax; and district traveling tax also show significant differences in taxation. In other words, various taxes have been imposed on fuel for transport as well as for heating; however, except for tariff no tax has been imposed on uranium or bituminous coal, which account for most of the electricity generation in Korea. The import levy tax to stabilize income has also been imposed on oil, but it has not been applied to uranium and bituminous coal. The fund for the development of the electricity industry has been created by the imposition of a $3.7 \%$ tax on electricity prices. Based on these taxation and pricing policies, it is possible to set a lower electricity price, which accelerates electrification in Korea.

The rate of taxation on electricity in Korea ranks below that of other major countries (see Fig. 4). The countries with a high proportion of taxes in electricity prices seek consistency in taxation, so they impose several powerrelated taxes such as additional environmental taxes to electricity and additional taxes on fuel for electricity generation.

In regard to energy tax policy, the Korean government has granted a minimal tax level or tax exemption on fuel related to electricity generation because the previous energy pricing policy minimized increases in the price of energy in terms of competitiveness within the industry and

Table 2. Status of energy tax system and dues in Korea (January 2012)

\begin{tabular}{|c|c|c|c|c|c|c|c|c|c|c|c|}
\hline & & \multirow{2}{*}{$\begin{array}{l}\text { Gasoline } \\
(\mathrm{KRW} / l)\end{array}$} & \multirow{2}{*}{$\begin{array}{c}\text { Diesel } \\
(\mathrm{KRW} / l)\end{array}$} & \multicolumn{2}{|c|}{ LPG(KRW/kg) } & \multirow{2}{*}{$\begin{array}{c}\mathrm{LNG} \\
\left(\mathrm{KRW} / \mathrm{m}^{3}\right)\end{array}$} & \multirow{2}{*}{$\begin{array}{l}\text { Kerosene } \\
(\mathrm{KRW} / l)\end{array}$} & \multirow{2}{*}{$\begin{array}{c}\text { Heavy oil } \\
(\mathrm{KRW} / l)\end{array}$} & \multirow{2}{*}{$\begin{array}{c}\text { Bituminous } \\
\text { coal }\end{array}$} & \multirow{2}{*}{$\begin{array}{c}\text { Uranium } \\
\text { (Nuclear Energy) }\end{array}$} & \multirow{2}{*}{$\begin{array}{l}\text { Electricity } \\
(\text { KRW/kwh) }\end{array}$} \\
\hline & & & & Butane & Propane & & & & & & \\
\hline \multirow{2}{*}{ Tariff } & Basis & $3 \%$ & $3 \%$ & $3 \%$ & $3 \%$ & $3 \%$ & $3 \%$ & $3 \%$ & $1 \%$ & - & - \\
\hline & assignment & $3 \%$ & $3 \%$ & $2 \%$ & $2 \%$ & $2 \%$ & $3 \%$ & $3 \%$ & - & - & - \\
\hline \multirow{2}{*}{$\begin{array}{c}\text { Individual } \\
\text { consumption tax (a) }\end{array}$} & Basis & - & - & $(252)$ & 0 & 48 & 90 & 17 & - & - & - \\
\hline & flexibility & - & - & 275 & 4 & - & - & - & - & - & - \\
\hline \multirow{2}{*}{$\begin{array}{l}\text { Transportation energy } \\
\text { environment tax (b) }\end{array}$} & basis & $(475)$ & $(340)$ & - & - & - & - & - & - & - & - \\
\hline & flexibility & 529 & 368 & - & - & - & - & - & - & - & - \\
\hline \multicolumn{2}{|c|}{ Educational tax $(\mathrm{a}, \mathrm{b} \times 15 \%)$} & 79 & 55 & 41 & - & - & 14 & 3 & - & - & - \\
\hline \multicolumn{2}{|c|}{$\begin{array}{l}\text { District traveling tax } \\
(\mathrm{b} \times(36 \%) 26 \%)\end{array}$} & $\begin{array}{c}(171) \\
138\end{array}$ & $\begin{array}{c}(122) \\
96\end{array}$ & - & - & - & - & - & - & - & - \\
\hline \multicolumn{2}{|c|}{ Import levy tax } & 16 & 16 & - & - & 20 & 16 & 16 & - & - & - \\
\hline \multicolumn{2}{|l|}{ Sales tax } & 36 & - & 62.28 & - & - & - & - & - & - & - \\
\hline \multicolumn{2}{|c|}{ Safety management tax ${ }^{b}$} & - & - & 4.5 & 4.5 & 3.9 & - & - & - & - & - \\
\hline \multicolumn{2}{|c|}{ Quality test fee } & 0.47 & 0.47 & 0.03 & 0.03 & - & 0.47 & 0.47 & - & - & - \\
\hline \multicolumn{2}{|c|}{$\begin{array}{l}\text { The fund for the development of } \\
\text { the electricity industry }\end{array}$} & - & - & - & - & - & - & - & - & - & $3.7 \%$ \\
\hline \multicolumn{2}{|l|}{ Other dues } & - & - & - & - & - & - & - & - & Three dues $^{\mathrm{d}}$ & - \\
\hline \multicolumn{2}{|c|}{ Value added tax $(\mathrm{VAT})^{\mathrm{c}}$} & \multicolumn{10}{|c|}{$10 \%$} \\
\hline
\end{tabular}

${ }^{a}$ District traveling tax is $36 \%$ according to local tax law, but it is applied to $26 \%$ under flexible tax rates

${ }^{\mathrm{b}}$ The safety management tax is for case of a gas explosion or other accident

${ }^{c}$ VAT is imposed on all energy sources

'Dues for used nuclear fuel processing, research and development fund of nuclear energy, and nuclear power providers' expense are included 


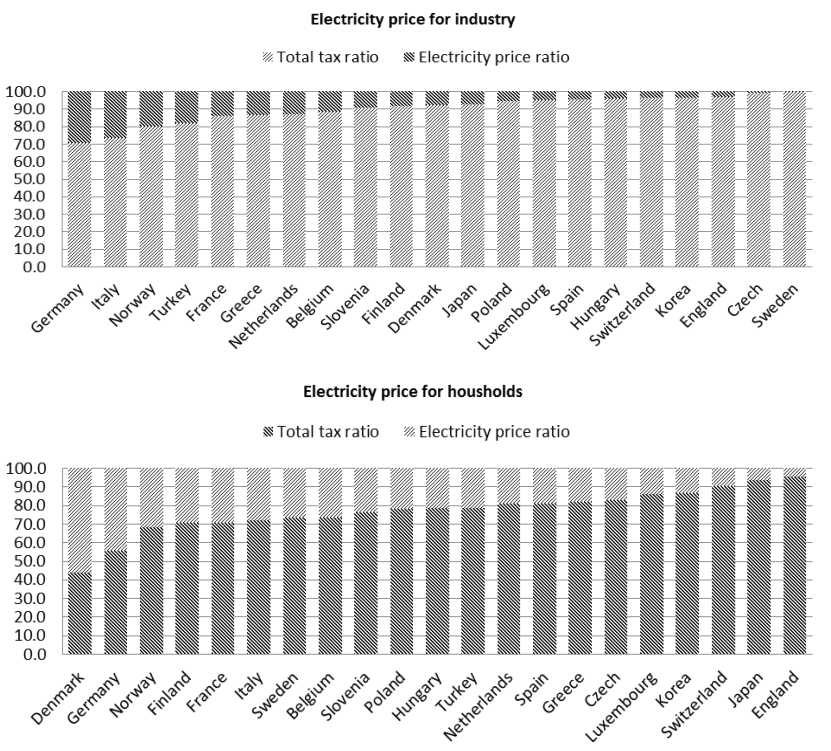

Fig. 4. Electricity price structure for main countries

Source: IEA Energy Prices and Taxes, IEA Statistics, 2012b

the price index [30]. Therefore, imposing a tax on the final goods instead of a tax on the same amount of intermediate goods is desirable to improve the competitiveness industry and to stabilize national prices of consumer goods and services. However, according to [30], the current energy system interrupts the distribution of renewable energy and the smart grid market. In addition, excessive differential taxation on individual energy sources brings about negative repercussions that not only inhibit fair competition between energy sources but also induces inefficiency in energy consumption. In other words, even if the development and adoption of energy conversion technologies are needed in energy system, excessive conversion of electricity into heating energy leads to inefficiency in energy use. A more detailed discussion of the inefficiency of energy consumption is provided in Section 2.2.3. Because energy pricing policy has changed from minimizing increases in the price of energy (improving competitiveness in the industry and stabilizing national prices of consumer goods and services) to inducing rational energy consumption [30], we need to consider a new energy taxation policy in Korea.

\subsection{Electricity pricing policy}

Korea's electricity pricing policy is a major cause of the rapid expansion of electricity consumption. Based on the Electricity Business Act of Korea, electricity price is subject to direct government regulation. In addition, electricity prices are classified according to intended use for household, business, and industry, and cross-subsidies among electricity prices are taken into account for a long period of time. ${ }^{10}$

${ }^{10}$ Based on the regulation of compensation rate on operating assets,
The four major characteristics of Korea's electricity pricing policy can be described as following: First, electricity price is determined by macro factors, such as industry competitiveness and price stability of consumer goods and services rather than supply and demand or generation cost. In other words, current electricity prices are suppressed to below the generation cost of electricity due to the price stabilization of consumer goods and services. Second, the cross-subsidy for usage base in Korea maintains cheaper electricity prices for industry while charging relatively high electricity prices for businesses and households. Third, while the individual consumption tax and import levies are imposed on natural gas, which is a relatively clean energy source compared to fossil fuels, there is no tax (excluding the value-added tax and customs duties) imposed on bituminous coal, which produces most of the carbon dioxide emissions and environmental pollutants. Forth, the cost of electricity generation by nuclear power plants in Korea is cheaper than other energy sources.

Due to these characteristics of Korea's electricity pricing policy, following problems occurred. First, Distortion of the electricity price structure makes it difficult to achieve rational energy consumption and consequently acts as a large burden on the national economy. In particular, a fixation on the energy-guzzling structure, a waste of foreign currency for importing energy and a waste of energy are concerned. In addition, it causes a distortion of the industry structure so that the long-term growth potential of the power supply and the reliability of the generation industry are compromised.

Second, a cross-subsidy inhibits fairness in the electricity pricing system. The cross-subsidy has the advantage of achieving policy objectives, such as improving social welfare and national competitiveness through a price system adjustment between electricity consumers that does not require the mobilization of a direct financial input from the government, regulation, or taxation. However, although policy objectives are achieved or changed, it is difficult to change prices which were formed by previous system of cross-subsidies. In this case, the cross-subsidy, contrary to the principle of burden on beneficiaries, harms fairness among consumers and generates deadweight loss by undermining the efficiency of resource allocation with distorted prices. In addition, it creates a problem in which products or services remain in the market even after economic conditions have changed and they are no longer competitive. In fact, the cross-subsidy for usage base in Korea is destroying fairness among consumers by charging high electricity prices for businesses and households that are relatively expensive while maintaining cheaper electricity prices for industry. Furthermore, the prices for

electricity price levels are determined by consultation with the Ministry of the Knowledge Economy, Ministry of Strategy and Finance, and National Assembly. 
each purpose do not reflect electricity generation costs, which hinder the efficient allocation of resources. In particular, as electricity consumption increases at midnight, electricity generation continuously depends on the LNG, a relatively expensive energy source, because surplus power from nuclear power and coal power plants is not enough. Although midnight electricity relies on expensive LNG electricity generation, midnight electricity is currently priced at low rates based on the cross-subsidy.

Third, external costs such as carbon dioxide and air pollutants are not included in energy market prices. Energy prices should reflect the external costs associated with environmental pollution or the risk of accidents in general. However, current electricity prices in Korea do not take into account these social costs. As a result, the electricity generation cost of bituminous coal and nuclear power plants that have the greatest effect on industrial prices are set low. Thus, the price of electricity is favorable relative to that of petroleum or natural gas.

Lastly, the cost of electricity generation by nuclear power plants in Korea has been badly distorted. This could be inferred indirectly from comparing the difference between nuclear electricity generation costs in Korea and Japan. After the Fukushima nuclear accident in 2011, a government-wide committee was established in Japan to re-estimate the cost of generating nuclear power by including social costs [31]. The cost of generating electricity from nuclear power was $¥ 5.9$ per $\mathrm{kWh}(0.06$ USD per $\mathrm{kWh}$ ) in 2004 , but it was estimated to be approximately $¥ 8.9$ per kWh (0.09 USD per kWh) in 2011 when social costs were included, which is a similar level to the cost of electricity generation from coal and LNG. In Korea in 2011, the purchase price of electricity from nuclear power through the KPE was 39.2 Korean won (KRW) per $\mathrm{kWh}^{11}$ (0.04 USD per $\left.\mathrm{kWh}\right)$, an amount less than half the price of the cost in Japan when social costs were included in the calculation. The method of price determination of electricity by generation source is still controversial, but social costs, such as the risk of accidents and decommissioning costs, should be included in the price of electricity in order to obtain a figure closer to the actual price.

\subsection{Distorted relative energy price system}

The energy conversion arising from differences in the relative price between energy sources is the underlying cause of rapid electrification of energy in Korea. In other words, it is necessary to consider the cause of electrification through a comparison of the relative price of energy because the market selects affordable sources to secure the same quantity of $\mathrm{cal}^{12}$. For this reason, relative

\footnotetext{
11 According to the Bank of Korea , 1 USD equaled 1,024 KRW in May 2014.

12 Energy consumers do not compare energy prices based on final energy, but only on useful energy level. Under the assumption of uniform
}
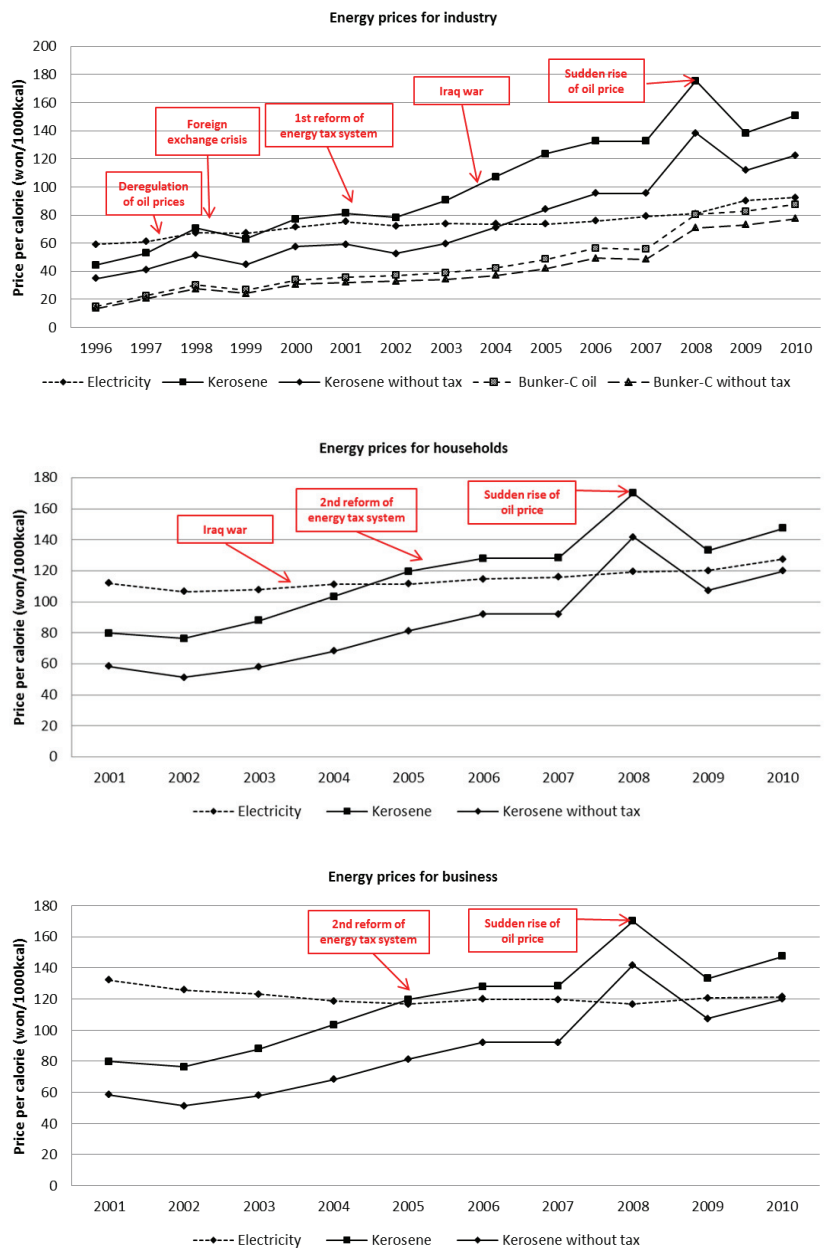

Fig. 5. Energy prices per cal. by energy sources

Source: $[22,33]$

Note: NCV conversion factor (electricity $817 \mathrm{kcal} / \mathrm{kWh}$, kerosene 7062 $\mathrm{kcal} / \mathrm{l}$, BUNKER-C oil $8868 \mathrm{kcal} / \mathrm{l})$

prices for industry, household, and business fuel and electricity in Korea were examined based on the price per cal. of fuel and electricity from 1996 to 2010.

First, Fig. 5 shows trends in industry pricing for kerosene, Bunker-C oil, and electricity. Oil prices were consistently high beginning in the late 1990s; during this period, the price of kerosene rose continuously. In the case of Bunker-C, the absolute price was low, but changes in the price show a similar pattern to that of kerosene. On the other hand, the price of electricity indicates a lower growth rate regardless of the pattern of oil prices. As a result, an inversion of the relative price between kerosene and electricity occurred in earnest in 2000, and the price difference between them has increased over time. Due to the inversion of the relative price of energy, electrification has been promoted and inefficient use of energy has been

conversion efficiencies, we can say that the comparison using final energy costs is only a rough approximation of consumer's cost-driven consumption decisions 
increased. If we consider the energy efficiency of conversion for kerosene and electricity, the amount of wasted energy can be measured. When we use kerosene and electricity for heating, energy efficiencies for kerosene and electricity are $80 \%$ and $38 \%{ }^{13}$ respectively. Therefore, if we use electricity for heating, the rate of wasted energy could be $42 \%$ compared with kerosene.

Energy taxation and electric charges in Korea are determined by government policy. The effects of this characteristic of Korean energy prices are revealed by comparing Korea to Japan and the OECD European countries. In Fig. 6, household energy prices of kerosene in Korea appear to be above the average of the OECD European countries. Electricity price is about $1 / 3$ the level of Japan and the OECD European countries, and the price of households' city gas is also less than in Japan and the OECD European countries. The price of household energy in major OECD European countries is higher for city gas, light oil products, and electricity. Japan is different from the OECD European countries in that city gas is more
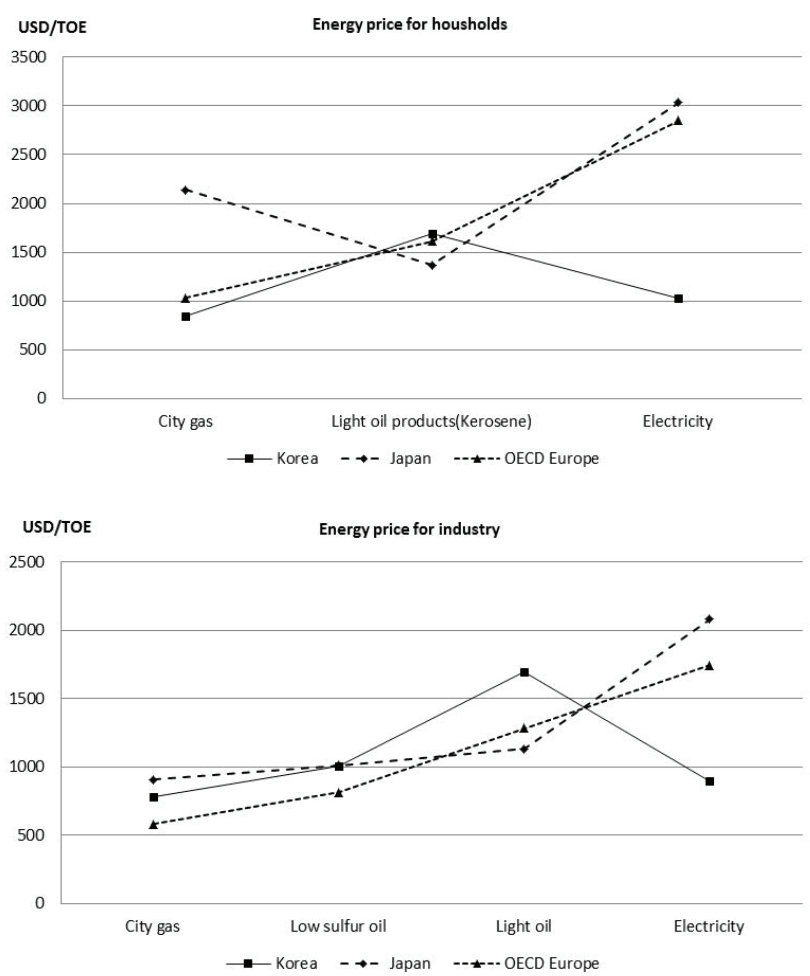

Fig. 6. Comparison of energy prices among Korea, Japan, and OECD Europe

Source: [33]

Note the price of kerosene is not provided in average price data of OECD European countries, so this study calculates the average price of kerosene from 21 countries in the OECD (Austria, Belgium, Czech Republic, Denmark, Estonia, Finland, France, Germany, Greece, Ireland, Italy, Luxembourg, Norway, Poland, Portugal, Slovenia, Spain, Sweden, Switzerland, Turkey, and the United Kingdom)

${ }^{13}$ Efficiency of conversion and thermal efficiency for electricity are $40 \%$ and $95 \%$, respectively [30]. expensive than light oil. This is because, unlike the OECD European countries that are using pipeline natural gas (PNG), Japan is using $\mathrm{LNG}$, which is more expensive because of the high cost of liquefaction, storage, and transport. Korea also uses LNG, but despite that fact, the city gas price is unusually lower than the price in the major OECD European countries using PNG.

Examining industrial energy prices, the price of heavy fuel oil in Korea is higher than in the OECD European countries and Japan, and the price of electricity in Korea is the lowest of the three. The reason for this is that the average electricity price for industry sector declined for light-load charges, which account for a large proportion of industrial electricity demand.

Comparison of the OECD European countries and Japan, Korea's household energy and industrial energy prices show that, in general, electricity prices in Korea are very cheap. In particular, the price of oil, a primary energy source, is lower than the price of electricity, a secondary energy source, in all compared countries; however, the reverse is true in Korea.

\section{Realignment of Energy Taxation and Electricity Price to Control Electrification}

The biggest problem with energy market distortion in Korea is the price system based on an inconsistent tax. The most widely used and reasonable energy tax criteria consider the environmental costs of a given type of energy. However, among the three major power sources (nuclear, bituminous coal, and LNG), the current energy tax for electricity generation is only imposed on LNG (see Table 2).

On the other hand, in spite of the fact that bituminous coal has the highest total carbon dioxide emissions (see Fig. 7), bituminous coal for electricity generation is exempt from an environmental tax. This goes against consistency and fairness. Thus, bituminous coal for electricity generation needs to be subject to consistent taxation based on carbon dioxide emissions.

In this study, a new carbon tax on bituminous coal for electricity generation that is proportional to its carbon dioxide emissions is considered. When applying a current

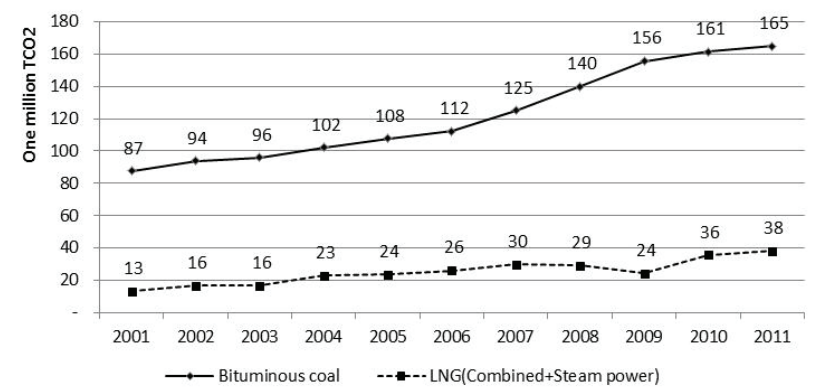

Fig. 7. Annual amount of $\mathrm{CO} 2$ emissions from electric generator fuel 
LNG tax as a standard to bituminous coal based on carbon dioxide emissions, additional tax revenues are generated.

The next item under consideration is the tax for compensation for potential damages from nuclear energy. Under the current system, in the case of an accident at a nuclear power plant, the cost of recovery and compensation for environmental damages will more than likely be paid by the government. Considering the high cost of damages from an accident at a nuclear power plant, it is necessary to transfer the burden from the government to the consumers in the long term. Looking at the recent case of the Fukushima accident in Japan, the expected compensation cost was estimated to reach about 8.7 trillion yen $(0.08$ trillion USD) in 2013 [34], with future costs coming to a total of 20 trillion yen ( 0.19 trillion USD) or higher over the next 10 years [35]. The Japanese government issued bonds to make up a large part of the deficit. They also proposed an electric price increase by the Tokyo Electric Power Company and a tax increase $(100 \%$ consumption tax hike), which were both approved. In case of nuclear power plant accidents, the compensation of liability is only 50 billion KRW ( 0.05 billion USD) per site for the operator in Korea. This is a very small amount even in light of the case of Japan, but to increase compensation more than 50 billion KRW ( 0.05 billion USD) could be a problem because there are no private insurance companies that could assume liability for the damages from a potential accident. Considering that nuclear power accidents have occurred steadily once per 5,000 reactor years $(500$ site $\times$ 10 year), it is necessary to reestablish the criteria for compensation measures in advance of a nuclear accident that may occur in the future based on the damage of the actual accident that occurred overseas. In other words, the purpose of a tax for compensation for nuclear damages is to normalize the potential damages by switching from both private insurance companies and the government, which bear a burden to electricity generation companies.

The idea behind a tax for compensation for the damages of nuclear power is basically to develop a new tax in which the operator bears the risk. Assuming a constant inflation rate for the sake of convenience, the compensation for damages is estimated based on the amount of compensation of Fukushima case. To estimate the compensation for damages in Korea, the amount of compensation of Fukushima case should be converted by the purchasing power parity (PPP) basis. Therefore, the amount of compensation for damages in Korea could be 66.9 trillion KRW (65.3 billion USD) on PPP basis. Assuming a 30 year nuclear abolition period and applying the commitment principle of total amount of retrieval of compensation from Korea Hydro and Nuclear Power in the same period, an application of a rate of $1 \%$ for 6 generators would allow for 2.67 trillion KRW (2.61 billion USD) to be recovered annually (see Table 3). Thus, 69.4 trillion KRW (67.8 billion USD) has been collected for 26 years, and it would cover the compensation for expected damages in Korea.
Table 3. Estimation results for the amount of compensation in Korea based on the case of the Fukushima nuclear accident

\begin{tabular}{l|c|c|c}
\hline $\begin{array}{c}\text { Nuclear power plant in } \\
\text { Korea }\end{array}$ & $\begin{array}{c}\text { Compensation } \\
\text { base } \\
\text { (a billion, } \\
\text { KRW) }\end{array}$ & $\begin{array}{c}\text { Compensation } \\
\text { rate }^{\mathrm{a}}\end{array}$ & $\begin{array}{c}\text { Amount of } \\
\text { compensation/ } \\
\text { year(one } \\
\text { hundred million, } \\
\text { KRW) }\end{array}$ \\
\hline Kori 1-4 plant & 66,917 & $0.66 \%$ & 4,417 \\
\hline Sinkori 1, 2 plant & 66,917 & $0.33 \%$ & 2,208 \\
\hline Youngkwang 1-6 plant & 66,917 & $1 \%$ & 6,692 \\
\hline $\begin{array}{l}\text { Wolsong 1-4 plant } \\
\text { Sinwolsong 1, 2 plant }\end{array}$ & 66,917 & $1 \%$ & 6,692 \\
\hline Uljin 1 - 6 plant & 66,917 & $1 \%$ & 6,692 \\
\hline \multicolumn{1}{c}{ Total } & & & $26,700^{\mathrm{b}}$ \\
\hline
\end{tabular}

${ }^{a}$ This study assumed that compensation rate for 6 generators is $1 \%$ and each generator has equal compensation rate. Thus, compensation rate for 2 and 4 generators is $0.33 \%$ and $0.66 \%$, respectively.

${ }^{\mathrm{b}}$ For 26 years, expected total amount of damages from nuclear power plants in Korea could be recovered.

\section{The Effects of Reforms to the Energy Tax System and Electricity Pricing}

\subsection{The change of tax revenue}

It is necessary to reform the energy tax and pricing system in order to prevent rapid electrification in Korea. There are a couple of principles to be considered: First, the relative price among energy sources should be rational. Second, social cost should be reflected in the price of each energy source. Based on these two principles, this section applies two reorganization plans (imposing a tax on bituminous coal for electricity generation and imposing a tax for compensation for damages from a potential nuclear accident) for energy taxation policies, which are suggested in section 3, to the Korean case and describes the effect of the change on generation cost/unit price and tax revenue.

First, we examine the effect of an increase in generation cost under the first item that imposes a tax on bituminous coal for electricity generation. Currently, the imposed taxes on LNG include tariff, consumption tax, import tariff, safety management tax, and value added tax (see Table 2). Among the taxes, the safety management tax is in case of a gas explosion or other accident, so this tax does not need to be imposed on bituminous coal as a new tax. In addition, a tariff is not considered a new tax for bituminous coal because a tariff is ad valorem duty. Thus, when we suggest a new tax, we only consider the consumption tax, import tariff, and value added taxes that are imposed on LNG. For this case, we can calculate that the tax on LNG is about $92,400 \mathrm{KRW}$ per ton; ${ }^{14}$ that could be changed to 33,000 KRW per $\mathrm{CO} 2$ ton based on the quantity of carbon emissions. This study assumes that the new tax for bituminous coal is applied proportionally based on the tax

${ }^{14}$ Excluding the tariff and safety management taxes 
on LNG imposed per $\mathrm{CO} 2$ emission, so the additional new tax on bituminous coal will be added to the total purchase cost of the Korean Electric Power Corporation (KEPCO). Table 4 provides the results of the introduction of a new tax. In Table 4, the increase in final purchase price of electricity is $29.4 \mathrm{KRW}$ per $\mathrm{kWh}$ which is a $43.7 \%$ increase compared to $67.2 \mathrm{KRW}$ per $\mathrm{kWh}$, the purchase price of electricity in 2011. ${ }^{15}$

For the second item, the tax for compensation for damages from a nuclear accident (see Table 3), this study recalculates insurance for nuclear energy based on the compensation insurance system of nuclear power plants in

Table 4. Effect of purchase price increases after considering new tax for bituminous coal

\begin{tabular}{l|c|c}
\hline $\begin{array}{l}\text { Purchase amount of bituminous coal } \\
\text { in } 2011\end{array}$ & Unit & Output \\
\hline $\begin{array}{l}\text { Total purchase cost of bituminous coal } \\
\text { in } 2011\end{array}$ & $\begin{array}{c}\text { One million } \\
\text { KRW }\end{array}$ & $12,487,529$ \\
\hline unit cost of bituminous coal in 2011 & KRW/kWh & 67.2 \\
\hline Carbon tax for bituminous coal $^{\mathrm{a}}$ & $\begin{array}{c}\text { One million } \\
\text { KRW }\end{array}$ & $5,453,783$ \\
\hline $\begin{array}{l}\text { Amount of increase in purchase price } \\
\text { after considering carbon tax }\end{array}$ & KRW/kWh & 29.4 \\
\hline
\end{tabular}

a According to [36], total amount of bituminous coal used in 2011 was $79,854,167$ ton. Therefore, total amount of $\mathrm{CO}_{2}$ emission was about 165 million ton. Based on the result of environmental tax for LNG $(33,000$ KRW per $\mathrm{CO}_{2}$ ton), total Carbon tax for bituminous coal could be about KRW 5,453,783 million.

Table 5. Effect of purchase price increases after considering new tax for nuclear energy

\begin{tabular}{l|c|c}
\hline & Unit & Output \\
\hline $\begin{array}{l}\text { Purchase amount of nuclear energy in } \\
2011\end{array}$ & MWh & $147,763,461$ \\
\hline $\begin{array}{l}\text { Total purchase cost of nuclear energy in } \\
2011\end{array}$ & $\begin{array}{c}\text { One million } \\
\text { KRW }\end{array}$ & $5,792,964$ \\
\hline Unit cost of nuclear energy in 2011 & KRW/kWh & 39.2 \\
\hline $\begin{array}{l}\text { Amount of compensation for damages } \\
\text { of nuclear energy }\end{array}$ & $\begin{array}{c}\text { One million } \\
\text { KRW }\end{array}$ & $2,669,988$ \\
\hline $\begin{array}{l}\text { Amount of purchase price increase } \\
\text { after considering compensation for } \\
\text { nuclear energy }\end{array}$ & KRW/kWh & 18.1 \\
\hline
\end{tabular}

Japan and assumes that the new tax for compensation insurance for nuclear energy is added to KEPCO's purchase price of electricity from nuclear power plants. Table 5 provides the results of the introduction of the new tax. Table 5 shows that the increase in final purchase price of electricity from nuclear power is $18.1 \mathrm{KRW}$ per $\mathrm{kWh}$ which is a $46 \%$ increase compared to $39.2 \mathrm{KRW}$ per $\mathrm{kWh}$, the purchase price of electricity from nuclear power in 2011.

In order to examine the change in the purchase price of electricity, we apply the first item, which adds a new tax to bituminous coal for electricity generation. The results show that the average purchase price of electricity is increased by $14.8 \%$; additional annual tax revenue is expected to be roughly 5.5 trillion KRW (5.37 billion USD). If both the first and second items are enacted as new energy policy, the average purchase price of electricity is increased by $22.0 \%$ as shown in Table 6 . Under these energy policies, additional annual tax revenue is expected to be approximately 8.2 trillion KRW ( 8.01 billion USD).

\subsection{Changes in the final sales price of electricity and actual tax revenue}

This section analyzes the change in the final sales price of electricity based on previous results in section 4.1. To analyze the change in final sales price of electricity, this study first examines the ratio of purchase price to sales price based on [37]. The financial statements show that the ratio of purchase price to sales price of electricity is $95.8 \%$. Therefore, if the purchase price of electricity is increased by $1 \%$, the sales price of electricity will increase by $0.958 \%$, under the assumption that sales price is raised in proportion to purchase price. Based on this information, Table 7 shows the final sales price of electricity when the first item (scenario 1) or both the first and second items (scenario 2) are applied, respectively. When the final sales price of electricity is calculated, the additional case in which $100 \%$ cost recovery is achieved for KEPCO is also considered, and the result is shown in Table 7.

Table 6. Amount the purchase price rises after considering both the first and second items

\begin{tabular}{|c|c|c|c|c|c|c|}
\hline & $\begin{array}{c}\text { The amount of } \\
\text { purchase power } \\
(\mathrm{MWh})\end{array}$ & $\begin{array}{l}\text { Total purchase cost with } \\
\text { recalculation } \\
\text { (a billion KRW) }\end{array}$ & $\begin{array}{c}\text { Unit cost } \\
(\mathrm{KRW} / \mathrm{kWh})\end{array}$ & $\begin{array}{l}\text { Previous unit cost } \\
\quad(\mathrm{KRW} / \mathrm{kWh})\end{array}$ & $\begin{array}{c}\text { Increase cost of } \\
\text { purchase }\end{array}$ & $\begin{array}{c}\text { Increase rate of } \\
\text { purchase cost }\end{array}$ \\
\hline Nuclear energy & $147,763,461$ & 8,463 & 57.3 & 39.2 & 18.1 & $46.1 \%$ \\
\hline Bituminous coal & $185,778,207$ & 17,941 & 96.6 & 67.2 & 29.4 & $43.7 \%$ \\
\hline Anthracite coal & $7,776,893$ & 767 & 98.6 & 98.6 & & \\
\hline Base & $337,987,435$ & 26,753 & 79.2 & 50.6 & 24.0 & $43.6 \%$ \\
\hline General & $124,369,292$ & 18,214 & 146.45 & 49.4 & & \\
\hline Total & $462,365,727$ & 44,967 & 97.3 & 79.7 & 17.6 & $22.0 \%$ \\
\hline
\end{tabular}

15 In order to calculate exact final price of electricity, the increase in sales
price of electricity generation companies should be analyzed first based
on the increase in fuel costs and then the increase in KEPCO's purchase price should be analyzed based on the sales price of electricity generation companies. However, owing to data limitations, this study adds additional tax to the purchase price. 
Table 7. Amount final consumer price rises

\begin{tabular}{|c|c|c|}
\hline & $\begin{array}{l}\text { Tax for } \\
\text { bituminous coal }\end{array}$ & $\begin{array}{c}\text { Tax for bituminous } \\
\text { coal and nuclear } \\
\text { energy }\end{array}$ \\
\hline $\begin{array}{l}\text { Previous unit cost of sales } \\
\text { (KRW/kWh) (basis of 2011) }\end{array}$ & \multicolumn{2}{|c|}{$89.32^{\mathrm{a}}$} \\
\hline $\begin{array}{l}\text { Recalculated unit cost of } \\
\text { sales (KRW/kWh) }\end{array}$ & $101.99(14.18 \%)$ & $\begin{array}{l}108.35 \\
(21.3 \%)\end{array}$ \\
\hline $\begin{array}{l}\text { Additional considerations of } \\
\text { cost recovery }\end{array}$ & $110.30(23.49 \%)$ & $116.46(30.39 \%)$ \\
\hline \multicolumn{3}{|c|}{$\begin{array}{l}\text { Note: Increase rate in parentheses } \\
\text { a This is calculated based on the monthly Report on Major Electric Power } \\
\text { Statistics in [36] and annual electric power statistics in [8]. } \\
\text { b The increase in sales prices of electricity is analyzed by using the news } \\
\text { release in [38]. }\end{array}$} \\
\hline
\end{tabular}

When the sales price of electricity increases, electricity demand decreases owing to the own elasticity of demand. Based on the results of [39], we analyze the own elasticity of demand and find that it is -0.53 . Table 8 shows the change in tax revenue and additional cost for achieving $100 \%$ cost recovery for KEPCO after considering the own elasticity of demand.

Table 8. Amount of change in tax revenue and cost recovery after considering elasticity of demand

\begin{tabular}{l|c|c}
\hline & $\begin{array}{c}\text { Tax for } \\
\text { bituminous coal }\end{array}$ & $\begin{array}{c}\text { Tax for bituminous } \\
\text { coal and nuclear } \\
\text { energy }\end{array}$ \\
\hline $\begin{array}{l}\text { The amount of increasing tax } \\
\text { revenue (one million, KRW) }\end{array}$ & 51,903 & 76,480 \\
\hline $\begin{array}{l}\text { The needed amount for cost } \\
\text { recovery (one million, KRW) }\end{array}$ & 33,156 & 31,781 \\
\hline
\end{tabular}

Determining the cost distribution for each sector (households, business, and industry) would require internal data from KEPCO that is not available to the public. Therefore, we assume in scenario 1 that additional costs from the first and second items are identically distributed for all purposes and in scenario 2 that additional costs from the first and second items are distributed only to the electricity price for industry. The sales price of electricity could be decided between scenario 1 and 2 . If the increase in purchase price of bituminous coal and nuclear power had a greater effect on the electricity price for industry, the results of an increase in the purchase price of electricity may align more closely with the results of scenario 2 . The results of scenario 1, which distributes the increase in purchase price equally among all sectors, are shown in Table 9; we also consider cost recovery of KEPCO.

Based on the results of Table 9, we can compare energy prices per cal. between primary energy sources and electricity. Among primary energy sources, we compare light oil (kerosene) and city gas with electricity for households and low sulfur oil and city gas with electricity for industry. This study mainly compares light oil (kerosene) and electricity prices for households and low sulfur oil and electricity prices for industry because conversion demand from heaters of both light oil (kerosene) and low sulfur
Table 9. Final consumer price increases for household, business, and industry in scenario 1

\begin{tabular}{|c|c|c|c|}
\hline & & $\begin{array}{c}\text { Tax for } \\
\text { bituminous } \\
\text { coal }\end{array}$ & $\begin{array}{c}\text { Tax for } \\
\text { bituminous coal } \\
\text { and nuclear } \\
\text { energy }\end{array}$ \\
\hline \multirow{3}{*}{$\begin{array}{l}\text { Previous unit cost } \\
\text { of sales for each } \\
\text { part (KRW/kWh) }\end{array}$} & Households & \multicolumn{2}{|c|}{119.99} \\
\hline & Business & \multicolumn{2}{|c|}{101.69} \\
\hline & Industry & \multicolumn{2}{|c|}{81.23} \\
\hline \multirow{3}{*}{$\begin{array}{l}\text { Unit cost of sales } \\
\text { for considering } \\
\text { cost recovery } \\
\text { (KRW/kWh) }\end{array}$} & Households & \multicolumn{2}{|c|}{$141.66(18.06 \%)$} \\
\hline & Business & \multicolumn{2}{|c|}{$108.99(7.18 \%)$} \\
\hline & Industry & \multicolumn{2}{|c|}{$87.91(8.23 \%)$} \\
\hline \multirow{3}{*}{$\begin{array}{l}\text { Recalculated unit } \\
\text { cost of sales }{ }^{\text {a }} \\
(\mathrm{KRW} / \mathrm{kWh})\end{array}$} & Households & $\begin{array}{c}159.14 \\
(32.64 \%)\end{array}$ & $168.54(40.46 \%)$ \\
\hline & Business & $\begin{array}{c}123.81 \\
(21.75 \%)\end{array}$ & $131.77(29.58 \%)$ \\
\hline & Industry & $\begin{array}{c}99.75 \\
(22.80 \%) \\
\end{array}$ & $106.11(30.63 \%)$ \\
\hline
\end{tabular}

Note: Increase rate in parentheses

${ }^{\text {a }}$ Considering both cost recovery and new tax for bituminous coal/ bituminous + nuclear energy

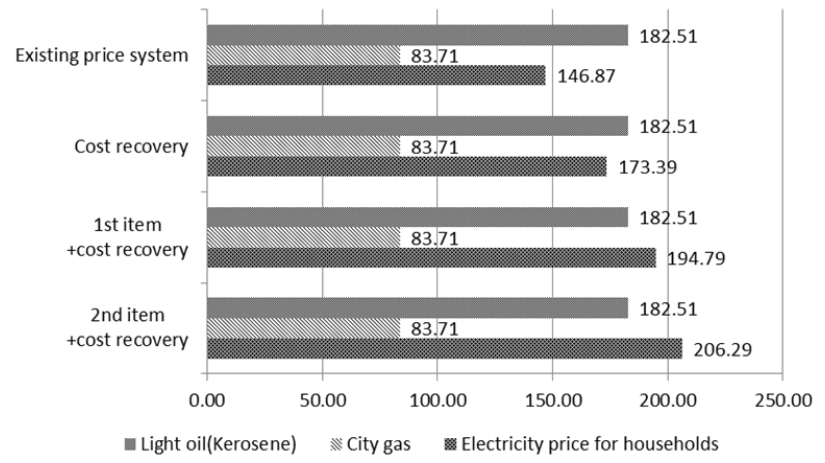

Fig. 8. Comparisons of energy prices for households among energy types in scenario 1 (base of cal. in 2011, KRW/1,000 kcal)

oil to electric heaters is one of the main reasons for electrification. Since the main problem of the energy market in Korea is that the primary energy price is more expensive than the secondary energy price, we examine the change in relative prices between oil and electricity after a reorganization of the tax system. The results are shown in Fig. 8.

First, for household electricity price, the results show that the electricity price per cal. is higher than the kerosene price per cal. after considering both the first and second items. However, because the electricity price system for households in Korea is set by a progressive stage system, the comparison between electricity price for households and energy price (kerosene) has limited meaning. In other words, under the electricity price system for households, consumers can use a backup heater and electric blanket instead of oil, but consumers are less likely to switch the whole heating system to electricity.

On the other hand, for electricity price for industry, the results show that the low sulfur oil price per cal., which is 


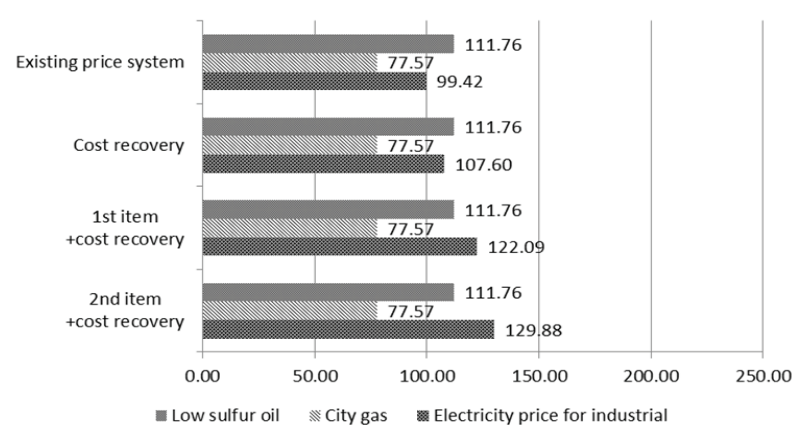

Fig. 9. Comparisons of energy prices for industry among energy types in scenario 1 (base of cal. in 2011, $\mathrm{KRW} / 1,000 \mathrm{kcal})$

Table 10. Final consumer price increases for households, business, and industry in scenario 2

\begin{tabular}{|c|c|c|c|}
\hline & & $\begin{array}{c}\text { Tax for } \\
\text { bituminous } \\
\text { coal }\end{array}$ & $\begin{array}{c}\text { Tax for } \\
\text { bituminous } \\
\text { coal and } \\
\text { nuclear energy }\end{array}$ \\
\hline \multirow{3}{*}{$\begin{array}{l}\text { Previous unit cost } \\
\text { of sales for each } \\
\text { part (KRW/kWh) }\end{array}$} & Households & \multicolumn{2}{|c|}{119.99} \\
\hline & Business & \multicolumn{2}{|c|}{101.69} \\
\hline & Industry & \multicolumn{2}{|c|}{81.23} \\
\hline \multirow{3}{*}{$\begin{array}{l}\text { Unit cost of sales } \\
\text { for considering } \\
\text { cost recovery } \\
(\mathrm{KRW} / \mathrm{kWh})\end{array}$} & Households & \multicolumn{2}{|c|}{$141.66(18.06 \%)$} \\
\hline & Business & \multicolumn{2}{|c|}{$108.99(7.18 \%)$} \\
\hline & Industry & \multicolumn{2}{|c|}{$87.91(8.23 \%)$} \\
\hline \multirow{3}{*}{$\begin{array}{l}\text { Recalculated unit } \\
\text { cost of sales }{ }^{\mathrm{a}} \\
(\mathrm{KRW} / \mathrm{kWh})\end{array}$} & Households & $\begin{array}{c}141.66 \\
(18.06 \%)\end{array}$ & $\begin{array}{c}141.66 \\
(18.06 \%)\end{array}$ \\
\hline & Business & $\begin{array}{c}108.99 \\
(7.18 \%)\end{array}$ & $\begin{array}{c}108.99 \\
(7.18 \%)\end{array}$ \\
\hline & Industry & $\begin{array}{c}109.64 \\
(34.97 \%)\end{array}$ & $\begin{array}{c}120.79 \\
(48.70 \%)\end{array}$ \\
\hline
\end{tabular}

Note: Increase rate in parentheses

${ }^{a}$ Considering both cost recovery and new tax for bituminous coal/ bituminous + nuclear energy

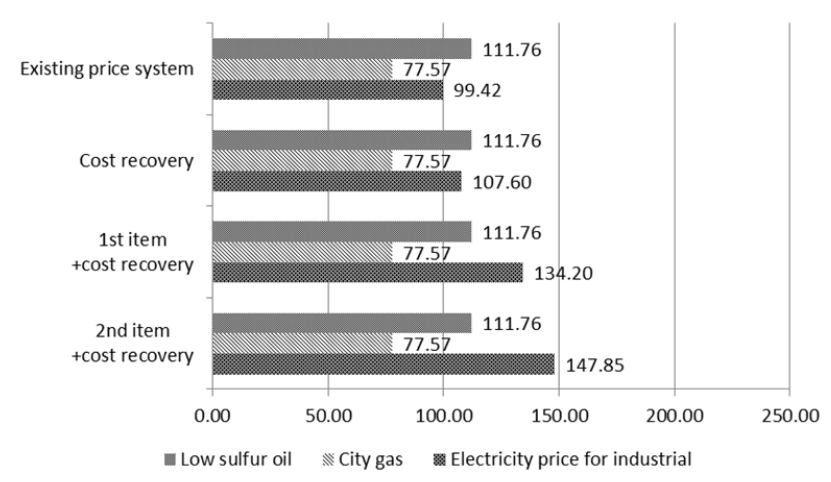

Fig. 10. Comparisons of energy prices for industry among energy types in scenario 2 (base of cal. in 2011, $\mathrm{KRW} / 1,000 \mathrm{kcal}$ )

mainly used in industry, and price of city gas per cal. are higher than the price of electricity for industry after considering both the first and second items. Therefore, if the government uses both the first and second items as energy policy, the relative prices between oil and electricity for industry could be improved.
The results of scenario 2, which distributes the additional cost from a new tax only to the electricity price for industry, are shown in Table 10. In this case, because the electricity price for industry increases more than in scenario 1, the relative prices for industry between electricity and oil are more greatly improved. These results are shown in Fig. 10.

\section{Conclusion and Policy Implications}

The energy mix in Korea can be summarized as a reduction in the use of fossil fuels and an expansion in the use of electricity; electrification is accelerated through the conversion demand from fossil fuels to electricity. The increase of electricity consumption along with the increase in national income and economic growth is a general trend, but the degree of concern about the possibility of blackout is very large owing to the rapid speed of electrification in Korea.

This rapid conversion into electricity is primarily triggered by distorted energy taxation and the electricity pricing policy in Korea. That is, an energy tax is imposed on oil for transport as well as for heating, but no tax exists on bituminous coal and uranium associated with electricity generation. Moreover, electricity prices have been set at less than their cost in order to reduce inflation and increase industry competitiveness in Korea, and the industry has benefited from lower electricity prices via cross-subsidies for many years. In addition, electricity prices do not take into account social costs that arise from its generation. Therefore, the relative price of oil compared with that of electricity has been worsening continuously in Korea. As a result, as energy electrification has accelerated, damage to the economy, society, and the environment have deepened, as has the instability of the power supply. However, energy policy has been changed from increasing industry competiveness/stabilizing the prices of consumer goods and services to inducing rational energy consumption.

Based on the awareness of these issues and changes to energy policy, we proposed a new energy price system to correct distortions in electricity pricing and energy taxes and to improve the energy consumption of the country. As a result, the relative price of oil compared with that of electricity is found to improve when compared with the current situation; this should result in a more rational consumption of energy and an increase in the revenue from taxes on energy sources. Moreover, the policy suggestions in this study could be utilized to establish a new energy policy and an energy system for preventing future blackouts in Korea. Currently, the introduction of competition in the electricity retail market is under discussion by the Korean government to increase the efficiency of the electricity market. However, for the successful introduction of competition in the electricity retail market, the electricity market should be based on the right price 
system considering relative prices of energy sources and social cost. In addition, the energy policy for stabilizing electricity market and improving energy efficiency in Korea such as energy demand management and identifying real-time power usage through automatic meter reading (AMR) system could be also successful when the right energy price system is established. Therefore, the results of this study can be widely used as the important information in a whole energy plans in Korea.

This study has several limitations. First, owing to the limited information about cost structure of electricity, it is difficult to provide the end-user price of electricity. If we had more information from KEPCO, a more accurate cost analysis would be possible. Second, according to the results of this study, it is necessary to increase the price of electricity and energy taxation in order to prevent electrification. Increasing electricity prices and energy taxation may increase the burden laid on the people and decrease industry competitiveness. In addition, social and political acceptability of increasing electricity price up to $22.0 \%$ could be lower than we expected. To mitigate these problems, the government could reduce the flexible taxrate for transport fuel (see Table 2) or reduce the corporate tax and income tax as in some European countries. Moreover, public acceptance of increasing electricity price should be analyzed based on the consumer's willingness to pay or accept. For instance, [40] and [41] analyzed public acceptance for Renewable Portfolio Standard (RPS) and Renewable Fuel Standard (RFS) policy, respectively. Third, this study did not consider the price ripple effect and the substitution effect among energy sources when the price of electricity increases. Lastly, this study did not analyze the effect of tax/pricing distortion and environmental regulations separately, and did not provide the final results by controlling these two issues. Therefore, to clarify the results of reorganization plans suggested in this study, the effect of tax/pricing distortion and environmental regulations on reorganization plans should be analyzed. Additional analyses mentioned above are needed in future studies.

\section{References}

[1] C. J. Andrews, "Reducing energy vulnerability," Proceedings of the ISTAS 2005, 2005, pp. 1-5.

[2] E. Gnansounou," Assessing the energy vulnerability: Case of industrialised countries," Energy Policy, Vol. 36, 2008, pp. 3734-3744.

[3] M. Reymond, "European key issues concerning natural gas: Dependence and vulnerability," Energy Policy, Vol. 35, 2007, pp. 4169-4176.

[4] H. Weisser, "The security of gas supply: A Critical issue for Europe?" Energy Policy, Vol. 35, 2007, pp. $1-5$.

[5] W. Kroger, "Critical infrastructures at risk: A need for a new conceptual approach and extended analytical tools," Reliability Engineering \& System Safety, Vol. 93, 2008, pp. 1781-1787.

[6] E. Van der Vleuten and V. Lagendijk, "Transnational infrastructure vulnerability: the historical shaping of the 2006 European "Blackout." Energy Policy, Vol. 38, 2010, pp. 2042-2052.

[7] P. Hines, J. Apt, and S. Talukdar, "Large blackouts in North America: Historical trends and policy implications," Energy Policy, Vol. 37, 2009, pp. 5249-5259.

[8] Korea Power Exchange, Annual electricity power statistics in 2011, 2012 (in Korean).

[9] Q. Zhang, K. N. Ishihara, B. C. Mclellan, and T. Tezuka, "Scenario analysis on future electricity supply and demand in Japan," Energy, Vol. 38, 2012, pp. 376-385.

[10] D. S. Callaway and I. A. Hiskens, "Achieving controllability of electric loads," Proceedings of the IEEE, Vol. 99, 2011, pp. 184-199.

[11] G. Strbac, "Demand side management: Benefits and challenges," Energy policy, Vol. 36, 2008, pp. 44194426.

[12] J. Torriti, M. G. Hassan, and M. Leach, "Demand response experience in Europe: Policies, programmes and implementation," Energy, Vol. 35, 2010, pp. 1575-1583.

[13] Q. K. Nguyen, "Cambodia's electricity sector in the context of regional electricity market integration," in Energy market integration in East Asia: Theories, electricity sector and subsidies, Y. X. Wu, Ed. Jakarta: ERIA, 2012, pp. 253-267.

[14] Y. T. Cho, Energy tax system and subsidy policy for sustainable energy system, Energy taxation policy seminar 2007 at The Korean Association of Public Finance, 2007 (in Korean).

[15] C. S. Kim and Y. T. Cho, "A Study on the Night Thermal-storage Power Service: Sustainability and Energy Security," Environmental and Resource Economics Review, Vol. 17, 2008, pp. 419-455 (in Korean).

[16] E. A. Abdelaziz, R. Saidur, and S. Mekhilef, S.," A review on energy saving strategies in industrial sector," Renewable and Sustainable Energy Reviews, Vol.15, 2011, pp. 150-168.

[17] H. Allcott, "Social norms and energy conservation," Journal of Public Economics, Vol. 95, 2011, pp. 1082-1095.

[18] I. Ayres, S. Raseman, and A. Shih, "Evidence from two large field experiments that peer comparison feedback can reduce residential energy usage," NBER Working Paper No. 15386, 2009

[19] P. Palensky and D. Dietrich, "Demand side management: Demand response, intelligent energy systems, and smart loads," IEEE Transactions on Industrial Informatics, Vol. 7, 2011, pp. 381-388.

[20] M. Castillo-Cagigal, A. Gutiérrez, F. MonasterioHuelin, E. Caamaño-Martín, D. Masa, and J. Jiménez- 
Leube, "A semi-distributed electric demand-side management system with PV generation for selfconsumption enhancement," Energy Conversion and Management, Vol. 52, 2011, pp. 2659-2666.

[21] A. G. Tsikalakis and N. D. Hatziargyriou, Centralized control for optimizing microgrids operation. In Power and Energy Society General Meeting, 2011 IEEE (pp. 1-8). IEEE, 2011.

[22] Korea Energy Statistics Information System (KESIS, https://www.kesis.net)

[23] IEA, Electricity Information, IEA Statistics, 2012a.

[24] IEA, Electricity Information, IEA Statistics, 2004.

[25] IEA, Electricity Information, IEA Statistics, 2006.

[26] IEA, Electricity Information, IEA Statistics, 2008.

[27] IEA, Electricity Information, IEA Statistics, 2010.

[28] Korea Energy Economics Institute (KEEI), Yearbook of Energy Statistics 2011, 2012. (in Korean)

[29] Korea Energy Economics Institute (KEEI), The Energy consumption survey in 2011. Ministry of Knowledge and Economy, 2011. (in Korean).

[30] Ministry of Trade, Industry and Energy (MOTIE), The $2^{\text {nd }}$ Korea national energy master plan, January 14, 2014. (in Korean)

[31] Y. Matsue, Summary and evaluation of cost calculation for nuclear power generation by the "Cost Estimation and Review Committee, The Institute of Energy Economics Japan, May 2012.

[32] Ministry of Commerce, Industry and Energy, The status of the midnight electricity service at night, 2007. (in Korean)

[33] IEA, IEA Energy Prices and Taxes (Third Quarter 2012), IEA Statistics, $2012 b$.

[34] K. Oshima, Damage of Fukushima nuclear accident and a new compensation scheme, 2013. from: http:// www.polsoz.fuberlin.de/polwiss/forschung/systeme/ff u/veranstaltungen/termine/archiv/pdfs_salzburg/Oshi ma.pdf?1367712373.

[35] Asia \& Japan Watch, Fukushima crisis estimated to cost from 5.7 trillion yen to 20 trillion yen. June 01 , 2011. from: http://ajw.asahi.com/article/0311disaster/ fukushima/AJ201106010334.

[36] Korean electric power corporation (KEPCO), The monthly Report on Major Electric Power Statistics, 2012a. (in Korean).

[37] Korean electric power corporation (KEPCO), Business Report in 2011, 2012c. (in Korean).

[38] Korean electric power corporation (KEPCO), News release material, 2012b. (in Korean).

[39] K.S. Park, "Issues on energy price system and its direction for improvement," Korean Energy Economic Review, Vol. 10, 2011, pp. 111-142.

[40] J. Shin, J. Woo, S. Huh, J. Lee, and G., Jeong, "Analyzing public preferences and increasing acceptability for the renewable portfolio standard in Korea," Energy Economics, Vol. 42, 2014, pp. 17-26.

[41] S. Huh, D. Kwak, J. Lee, and J. Shin, "Quantifying drivers' acceptance of renewable fuel standard: Results from a choice experiment in South Korea," Transportation Research Part D: Transport and Environment, Vol. 32, 2014, pp. 320-333.

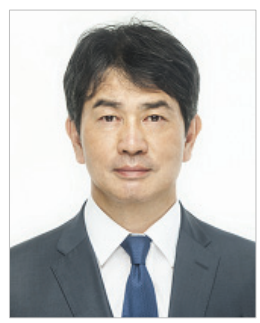

Changseob Kim He received Ph.D degree in electrical engineering from Seoul National University. My research interests are energy policy, smart grid, climate change.

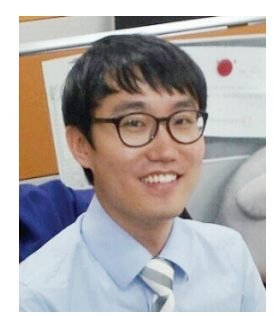

Jungwoo Shin He received a B.S. in mathematics from the Korea Advanced Institute of Science and Technology Daejeon, Korea, and a Ph.D. from the Technology Management, Economics, and Policy Program at Seoul National University, Korea. $\mathrm{He}$ is currently a research fellow in the environmental policy research group at Korea Environment Institute, Korea. His research interests include demand forecasting and the economic impacts of new products, service and R\&D management, and consumer behavior. 